\title{
Mekanisme Konsultasi Publik :Instrumen Pembangun Good Governance Di Daerah
}

\author{
Zulkarnain Ridlwan \\ Bagian Hukum Tata Negara Fakultas Hukum Unila \\ Jl. Soemantri Brodjonegoro No. 1 Bandar Lampung 35145, \\ email : zulkarnainridlwan@gmail.com
}

\begin{abstract}
Abstrak
Tujuan penulisan ini adalah untuk mendeskripsikan pentingnya ketersediaan mekanisme konsultasi publik dalam perumusan kebijakan dan peraturan ditingkat daerah. Berdasarkan tinjauan teoritis, filosofis, sosiologis, dan yuridis disimpulkan bahwa tersedianya mekanisme konsultasi publik di daerah sejalan dengan prinsip tata pemerintahan yang baik (good governance) oleh karena itu bagi daerah perlu mengadopsi pengaturannya di tingkat daerah.
\end{abstract}

\section{Kata Kunci : Mekanisme Konsultasi Publik, Good Governance}

\section{Pendahuluan}

Masa reformasi pasca runtuhnya Orde Baru di Indonesia telah membuka banyak hal positif, diantaranya semangat untuk menghasilkan kebijakan publik yang lebih berpihak kepada rakyat. Hal terpenting dalam proses kebijakan publik adalah formulasi (perumusan) kebijakan. ${ }^{1} \quad$ Pada tahap formulasi kebijakan ini keterlibatan publik untuk ambil peran sangatlah penting, hal ini dapat dirumuskan dalam berbagai tinjauan; filosofis, sosiologis, dan yuridis.

Secara filosofis, tujuan pembangunan nasional adalah mewujudkan masyarakat adil dan makmur yang merata material dan spiritual berdasarkan Pancasila dan Undang-Undang Dasar 1945 dalam wadah Negara Kesatuan Republik Indonesia yang merdeka, berdaulat, bersatu, dan berkedaulatan rakyat dalam suasana perikehidupan bangsa yang aman, tenteram, tertib, dan

1 Leo Agustio, Dasar-dasar Kebijakan Publik, (Bandung: Alfabeta, 2008), hlm. 96. dinamis dalam lingkungan pergaulan dunia yang merdeka, bersahabat, tertib, dan damai. Pembangunan nasional sebagai pengamalan Pancasila yang mencakup seluruh aspek kehidupan bangsa diselenggarakan bersama oleh masyarakat dan Pemerintah. Masyarakat adalah pelaku utama pembangunan dan Pemerintah berkewajiban mengarahkan, membimbing, melindungi serta menumbuhkan suasana yang menunjang. Kegiatan masyarakat dan kegiatan Pemerintah saling menunjang, saling mengisi, dan saling melengkapi dalam satu kesatuan langkah menuju tercapainya tujuan pembangunan nasional.

Salah satu wujud implementasi nyata warga negara Indonesia dalam menjalankan kedudukan, hak, kewajiban, dan peran serta masyarakat adalah keterlibatan aktif dalam penyelenggaraan negara. Hal ini juga berlaku bagi masyarakat ditingkat daerah. Oleh karena itu, penyediaan mekanisme konsultasi 
publik bagi eksekutif maupun jenis lainnya bagi legislatif dalam pembangunan nasional sangat penting untuk mendapat perhatian.

Hingga saat ini sarana dan upaya untuk memberikan kesempatan interaksi aktif antara pemerintah daerah dengan masyarakat untuk sharing pendapat dalam penyusunan kebijakan publik belum berjalan, termasuk di tingkat daerah. Pentingnya aksesibilitas publik kepada lingkungan pemerintahan -khususnya dalam penyusunan kebijakan dapat memungkinkan publik untuk menikmati sepenuhnya semua hak asasi manusia dan kebebasan fundamental.

Secara sosiologis, penyedian mekanisme konsultasi publik sejalan dengan prinsip keadilan sosial yang merupakan nilai dasar bernegara di Indonesia. Mekanisme konsultasi ini diharapkan dapat meningkatkan peran serta masyarakat dalam penyusunan kebijakan. Canter sebagaimana dikutip Santosa mendefinisikan peranserta masyarakat sebagai proses komunikasi dua arah yang terus menerus untuk meningkatkan pengertian masyarakat atas suatu masalah-masalah dan kebutuhan. Bentuk kegiatannya meliputi feed forward information (komunikasi dari pemerintah kepada masyarakat tentang suatu kebijakan) dan feedback information (komunikasi dari masyarakat ke pemerintah atas suatu kebijakan) $)^{2}$.

2 Aan Eko Widiarto, Garis Politik dan Peruandang-undangan dalam Desentralisasi Pengelolaan Lingkungan Hidup menuju Model Pengelolaan Lingkungan Hidup yang Berdimensi Peran Serta Masyarakat di Daerah, (Malang: Skripsi, 1999), Hal. 40-42.
Pada dasarnya peran serta masyarakat merupakan insentif moral sebagai alat untuk mempengaruhi lingkup makro yang lebih tinggi di tempat dibuatnya keputusan-keputusan yang sangat menetukan kesejahteraan masyarakat. Dengan demikian penyediaan mekanisme peran serta masyarakat juga berkaitan dengan kesejahteraan sosial. Hal ini dimungkinkan dengan argumentasi bahwa diaturnya mekanisme konsultasi publik berarti membuka kesempatan bagi masyarakat untuk memberi masukan, pendapat, pandangan, ide, dan saran yang sesuai dengan kepentingan dan kebutuhan yang dirasakan masyarakat. Asupan aspirasi publik ini pada tahap selanjutnya akan mewarnai kebijakan publik yang diambil pemerintah daerah. Sehingga pada akhirnya seluruh kebijakan publik yang dibuat akan selalu berbanding lurus dengan kepentingan dan kebutuhan masyarakat.

Dengan demikian peran serta tersebut bukanlah sebuah tujuan akhir (participation is an end itself). Hal ini tentunya bertolak belakang dengan asumsi yang berkembang selama ini yang memandang peran serta masyarakat semata-mata sebagai penyampaian informasi (public information), penyuluhan, bahkan hanya sekedar alat public relation agar proyek-proyek yang dilakukan pemerintah dapat berjalan lancar dan mendapat legitimasi dari masyarakat. Cormick membedakan peran serta masyarakat ke dalam dua pola, yaitu ${ }^{3}$ pertama; peran serta masyarakat yang bersifat konsultatif

\footnotetext{
3 Mas Achmad Santosa dan Arimbi BP, Peran Serta Masyarakat dalam Pengelolaan Lingkungan Hidup, (Jakarta: WALHIYLBHI, 1993), hlm. 1-2.
} 
yang berarti dalam hubungan antara pihak pejabat pengambil keputusan dengan kelompok masyarakat yang berkepentingan, masyarakat mempunyai hak untuk di dengar pendapatnya dan untuk diberitahu. Keputusan akhir masih tetap berada pada pembuat keputusan. Kedua; Peran serta masyarakat yang bersifat kemitraan. Dalam pola ini, pejabat pembuat keputusan dan anggotaanggota masyarakat merupakan mitra yang relatif sejajar kedudukannya. Mereka bersama-sama membahas masalah, mencari alternatif pemecahan masalah dan membuat keputusan. Kedua pola tersebut sama-sama dapat diterapkan. Yang terpenting adalah ugensitas keberadaan suatu mekanisme publik untuk didengar dan diperhatikan pendapatnya, dapat disediakan di tingkat pemerintahan daerah.

Adapun secara yuridis, cukup banyak dasar hukum yang melandasi pentingnya diatur mekanisme konsultasi publik ditingkat daerah. Dasar hukum tersebut memiliki keragaman klausula, namun punya kesatuan semangat, yaitu pelibatan masyarakat dalam pemerintahan khususnya dalam pembentukan dan penyusunan kebijakan daerah. Peraturan perundang-undangan yang menjadi dasar hukum ini mengatur tentang peran serta masyarakat sebagai penghargaan terhadap hak menyampaikan pendapat, hak dalam komunikasi dan informasi, upaya pembentukan pemerintahan yang bebas dari KKN, pelayanan publik, hingga menjadi asas dalam pembentukan peraturan perundangundangan. Termasuk pengaturan badan publik mana saja yang menjadi pelaksana dan atau diwajibkan untuk membuka diri terhadap aspirasi dan masukan pendapat masyarakat.

Berdasar pada tinjauantinjauan tersebut, dapat diketahui bahwa keberadaan mekanisme konsultasi publik telah sejalan dengan nafas reformasi yang menghilangkan kesan elitis dalam pembuatan kebijakan publik. Disebut berkesesuaian dengan nafas reformasi karena peraturan perundang-undangan yang mengatur tentang partisipasi dan pelibatan publik secara rigid dilahirkan pada rentang tahun 1998 hingga sekarang. Sebelumnya pada masa Orde Baru, pelibatan masyarakat hanya berhenti pada rumusan normatif, tanpa pernah menemukan realisasi dalam prakteknya. Masih sejalan dengan semangat pembaharuan tata hubungan antara pemerintah dengan masyarakat, telah cukup lama diperkenalkan prinsip good governance. Kesamaan dalam semangat, mendasari pembahasan mengenai keterkaitan antara dua hal ini termasuk saling ketergantungan antara keduanya dalam membentuk tata pemerintahan yang baik, khususnya ditingkat daerah.

\section{Kriteria Good Governance}

Setidaknya ada tujuh kriteria yang harus dipenuhi untuk dapat membentuk mekanisme yang menghasilkan good governance. Kriteria-kriteria tersebut adalah sebagai berikut ${ }^{4}$ :

1. Adanya legitimasi atau
dukungan yang kuat dari
masyarakat terhadap institusi
publik baik yang berwujud

4 Lijan Poltak Sinambela, Reformasi Pelayanan Publik; teori, kebijakan, dan implementasi, (Jakarta: Bumi Aksara, 2007), hlm. 51. Mengutip Muhammad Agus Yusoff, Op.Cit., hlm. 11-12. 
sebagai lembaga birokrasi maupun institusi lainnya yang dibentuk masyarakat secara swadaya.

2. Adanya kebebasan dalam berpendapat untuk menyampaikan aspirasi atau kepentingan bagi setiap institusi ataupun kelompok masyarakat yang ada (stakeholders) sehingga seluruh stakeholders tersebut dapat berpartisipasi aktif dalam semua proses pembangunan. Kebebasan untuk berpendapat dan berpartisipasi tersebut tentunya juga harus didukung oleh adanya kebebasan yang bertanggung jawab bagi media-media dalam masyarakat.

3. Adanya keadilan serta kerangka legal berupa kepastian hukum untuk menjamin upaya penegakan keadilan tersebut.

4. Adanya akuntabilitas dan transparansi dalam mekanisme birokrasi.

5. Tersedianya informasi pembangunan yang dapat diakses oleh masyarakat dengan mudah dan bebas.

6. Terciptanya efektivitas dan efisiensi dalam penyediaan pelayanan publik.

7. Terbentuknya kerja sama yang baik antara pemerintah dan civil society organization.

Asas atau prinsip perumusan peraturan (juga ditingkat daerah) dalam rangka pembangunan berkelanjutan juga menyebutkan bahwa pada konferensi Persatuan Bangsa-Bangsa (PBB) tentang Lingkungan Hidup dan Pembangunan di Rio de Janeiro tahun 1992, negara-negara anggota PBB beserta perwakilan dari lembaga swadaya masyarakat di seluruh dunia telah menyetujui sebuah dokumen yang disebut dengan Agenda 21. Dokumen tersebut merupakan cetak biru dari langkah yang akan dilaksanakan oleh pemerintah dan organisasi masyarakat di seluruh dunia mengenai dampak yang dapat ditimbulkan oleh manusia terhadap lingkungan hidup. Beberapa prinsip di dalam Agenda 21 sangat relevan di dalam menambah wawasan perancang peraturan perundangundangan di daerah, antara lain sebagai berikut:

a) Keadilan antar generasi;

b) Keadilan dalam satu (sesama) generasi;

c) Partisipasi rakyat dalam proses pengambilan keputusan dan akses rakyat terhadap informasi;

d) Internalisasi biaya lingkungan dan pengembangan instrument ekonomi;

e) Kerja sama internasional dalam pengembangan kapasitas serta dalam pencegahan relokasi kotor;

f) Prinsip pencegahan dini;

g) Peran penting perempuan dan pemuda dalm pengelolaan lingkungan hidup;

h) Pengakuan hak masyarakat asli;

i) Pengembangan pengetahuan dan praktek masyarakat tradisional dalam pengelolaan lingkungan;

j) Keterkaitan erat antara perdamaian, pembangunan, dan perlindungan lingkungan.

Prinsip-prinsip yang terdapat di dalam Agenda 21 kemudian secara popular dikenal dengan prinsip Pembangunan Berkelanjutan Berbasiskan Tata Pemerintahan Yang Baik (Good Sustainable Development Governance) disingkat "GSDG". Dalam mewujudkan pembangunan berkelanjutan dengan berbasiskan tata pemerintahan yang 
baik atau GSDG maka kerjasama antara tiga elemen masyarakat adalah sangat penting. Ketiga elemen masyarakat tersebut adalah pemerintah, pelaku usaha, dan organisasi masyarakat sipil (civil society organization). Konsep GSDG ini apabila diterjemahkan dalam konteks daerah maka peran pemerintah daerah di dalam mengeluarkan peraturan-peraturan daerah yang berorientasi terhadap pembangunan berkelanjutan adalah sangat penting. Disamping itu, penekanan bahwa adanya keharusan untuk melibatkan masyarakat dalam pengambilan keputusan.

Tersedianya kesempatan luas untuk mengoreksi, memperbaiki, dan atau menganulir setiap kebijakan pemerintah dan pembangunan, karena pada kenyataannya tidak berkesesuaian dengan kepentingan masyarakat lokal, nasional, regional, ataupun dalam konteks kepentingan global.

\section{Mekanisme Konsultasi Publik dalam Prinsip Good Governance}

Kata publik mempunyai dua arti yang berbeda. Pertama, publik diartikan sebagai negara atau pemerintah seperti dalam terjemahan public administration menjadi Administrasi Negara. Kedua, kata publik sebagai padanan dari kata umum seperti dalam kata public telephone (telepon umum), public transportation (transportasi umum), dan atau public interest (kepentingan umum). Sehubungan dengan biasnya pemaknaan mengenai arti publik tersebut di atas, mungkin perlu pula diusulkan pembakuan istilah administrasi publik untuk mengganti administrasi negara dengan harapan bahwa kepentingan umum akan menjadi perhatian utama (main concern) dari administrasi publik, baik pada aras konsep maupun pada tataran praksis, dan bukan kepentingan kekuasaan negara seperti yang selama ini terjadi. ${ }^{5}$

Pengertian istilah publik dapat ditelusuri menurut asal katanya (secara etimologis). Dalam bahasa Inggris, kata publik (public) dalam ditemukan dalam dua bentuk. Pertama, sebagai kata benda (the public) yang berarti the community in general atau part of community having a particular interest in common. Kedua, sebagai kata sifat (public) yang dapat berarti of or concerning people in general atau provided, especially by affairs, entertainment, service, etc. of the people atau open or known to people in general. Dari pengertian tersebut diatas dapat dimengerti secara garis besar, bahwa kata publik dalam bahasa Ingris sangat erat berhubungan dengan segala sesuatu yang menyangkut masyarakat atau orang banyak seperti yang juga terkandung dalam kosa kata bahasa Indonesia. ${ }^{6}$

Adapun istilah konsultasi publik (public consultation) bersama dengan istilah dengar pendapat umum (public hearing) adalah dua istilah yang menjadi popular dengan berkembangnya proses-proses partisipatif dalam penentuan kebijakan dan perumusan/ penyusunan peraturan perundangundangan yang tentunya akan berdampak bagi warganegara. Konsultasi publik merupakan istilah yang sering terkait dengan proses yang dilakukan oleh eksekutif, sedangkan dengar pendapat umum lebih sering terkait dengan proses yang dilakukan di gedung dewan

\footnotetext{
${ }^{5}$ Leo Agustio, Op.Cit.., hlm. 213.

${ }^{6}$ Ibid..
} 
oleh kalangan legislatif. Meskipun sebenarnya legislatif juga dapat melakukan konsultasi publik di daerah-daerah untuk memperoleh masukan mengenai suatu rancangan peraturan perundang-undangan yang sedang disusunnya. Konsultasi Publik yang dilakukan pemerintah untuk melibatkan warga negara dalam merumuskan sebuah kebijakan atau peraturan akan membangun terjadinya hubungan dua arah antara pemerintah dan warganegara. Di sini, peran penting warganegara dan para pemangku kepentingan (stakeholders) lain diakui oleh pemerintah. ${ }^{7}$

Pelibatan masyarakat dalam pengelolaan urusan publik sejalan dengan prinsip pengelolaan yang amanah. Menurut Bintoro Tjokroamidjojo, ${ }^{8}$ bahwa pemahaman konsepsi pengelolaan kepemerintahan yang amanah dapat dijelaskan dengan prinsip-prinsip sebagai berikut:

1. Akuntabilitas, tanggung gugat (accountability). Akuntabilitas adalah kewajiban untuk memberikan pertanggungjawaban atas kinerja dan tindakan pimpinan suatu organisasi kepada publik yang memiliki hak

7 Pengantar Resensi buku Memfasilitasi Kebijakan Publik; Refleksi Pengalaman Penyusunan Rancangan Peraturan Pemerintah tentang Tahapan, Tata Cara Penyusunan, Pengendalian, dan Evaluasi Pelaksanaan Rencana Pembangunan Daerah (RPP- T2CP2EPRPD) yang diterbitkan oleh FPPM, BIGS, USAIDDRSP dan Dirjen Bina Bangda Depdagri. Sebagaimana dipublikasikan dalam http://jrki.wordpress.com/category/resensibuku/.

8 Muhammad Agus Yusoff dan Rusman Ghazali, Otonomi Daerah, Partisipasi, dan Good Governance. (Jurnal Ilmu Sosial dan Ilmu Politik LABSOSPOL FISIP - UNAS, 2003), hlm. 8-9. meminta pertanggungjawaban. Kalau salah pemerintahan dapat digugat oleh rakyat sebagai penerima pelayanan masyarakat.

2. Transparansi (transparency). Dapat diketahui oleh pihak yang berkepentingan mengenai kebijaksanaan pemerintah dan organisasi badan usaha. Seleksi jabatan berdasar fit and proper test, tender pelelangan, pemberian izin dilakukan secara transparan.

3. Keterbukaan (openess). Pemberian informasi secara terbuka, terhadap saran dan kritik yang dianggap sebagai partisipasi masyarakat untuk perbaikan.

4. Berdasarkan hukum (rule of law). Keputusan, kebijakan pemerintah, organisasi dan badan usaha yang menyangkut kepentingan publik dilakukan berdasarkan hukum (peraturan perundang-undangan yang berlaku). Jaminan kepastian hukum dan rasa keadilan masyarakat terhadap setiap kebijakan publik yang ditempuh. Conflict resolution (penyelesaian konflik) berdasarkan hukum.

5. Jaminan fairness, a level playing field (perlakuan yang adil/perlakuan kesetaraan). Ini berlaku bagi pemerintah kepada masyarakat dalam pelayanan publik, perusahaan kepada pelanggan dan sebagainya.

Prinsip-prinsip tersebut dapat diwujudkan dalam sistem pemerintahan, jika ada partisipasi luas dari stakeholders untuk berperan aktif. United Nation Development Program (UNDP) merumuskan, ${ }^{9}$ bahwa setidaknya ada tiga pihak yang berperan sebagai pelaku dalam good governance yaitu (i) negara atau pemerintah; (ii) sektor private;

\footnotetext{
${ }^{9}$ Ibid., hlm. 9.
} 
dan (iii) civil society. Setiap pelaku tersebut memiliki peran masingmasing demi terbentuknya good governance. Partisipasi tersebut pada akhirnya akan menyediakan kesempatan luas untuk mengoreksi, memperbaiki, dan atau menganulir setiap kebijakan pemerintah dan pembangunan, karena pada kenyataannya tidak berkesesuaian dengan kepentingan masyarakat.

Pengalaman menunjukkan bahwa peran serta publik dalam setiap proses perencanaan pembangunan dapat memberi keyakinan kepada kita bahwa, warga masyarakat sebagai entitas politik, ekonomi, sosial, dan budaya tidak hanya dapat dipersepsikan sematamata sebagai objek pembangunan. Akan tetapi, juga entitas yang perlu mendapat ruang cukup bebas sebagai subjek pembangunan itu sendiri.

Peran serta publik juga tidak hanya diartikan sebagai instrumen untuk mensosialisasikan program pemerintah dan pembangunan, melainkan sebagai upaya sadar untuk melibatkan masyarakat dalam konteks proses penentuan kebijakan publik. Itulah sebabnya, perkuatan otonomi daerah (dengan demokratisasi) harus terus digalakkan untuk semakin mendekatkan peran serta warga masyarakat dalam setiap proses penentuan kebijakan atau program pembangunan. ${ }^{10}$

Keinginan masyarakat untuk melibatkan diri juga merupakan faktor yang cukup dominan akibat semakin meningkatnya kesadaran dan kemampuan untuk bertumbuh, berdaya, dan berkembang menjadi civil society. Di mana warga masyarakat semakin paham akan hak

\footnotetext{
${ }^{10}$ Ibid.
}

dan kewajiban mereka dalam pengelolaan persoalan-persoalan publik. Oleh sebab itu, partisipasi publik dalam proses pemerintahan dan pembangunan perlu ditegaskan sebagi upaya yang paling efektif dalam konteks penciptaan kondisi ideal hubungan antara pemerintah dengan masyarakat disemua tingkat pemerintahan termasuk ditingkat daerah.

Salah satu kunci utama dari pengelolaan kebijakan yang berkualitas adalah tingginya intensitas partisipasi publik. Sebab kesahihan kebijakan publik apa pun dari pemerintahan terletak di sana. Dialog dengan publik adalah kebenaran suatu kebijakan dan menjadi sarana utama untuk kebijakan yang siap digunakan. Partisipasi dalam kebijakan adalah suatu aktivitas, proses, dan sistem pengambilan keputusan yang mengikutsertakan semua elemen masyarakat yang berkepentingan terhadap sukses suatu rencana. Tujuan utama dari partisipasi adalah mempertemukan seluruh kepentingan yang sama dan yang berbeda dalam suatu proses perumusan dan penetapan kebijakan (keputusan) secara proporsional untuk semua pihak yang terlibat dan terpengaruh oleh kebijakan yang akan ditetapkan dalamnya. Pelibatan masyakat luas (publik) dalam proses penentuan kebijakan merupakan satu cara efektif untuk menampung dan mengakomodasi berbagai kepentingan yang beragam. Pengikutsertaan publik yang terwujud dalam perencanaan yang partisipasi dapat membawa keuntungan substansif, di mana keputusan publik yang diambil akan memberi rasa kepuasan dan dukungan publik yang cukup kuat 
terhadap suatu proses pembangunan. Keterlibatan masyarakat dalam proses penentuan kebijakan publik yang dapat memberikan nilai strategis bagi masyarakat itu sendiri menjadi salah satu syarat penting dalam upaya pembangunan politik, ekonomi, sosial, dan budaya. ${ }^{11}$

$$
\text { Di negara maju }{ }^{12}
$$

partisipasipasi publik telah lama menjadi agenda yang mapan dalam sistem pemerintahan dan pembangunan untuk setiap proses pengambilan keputusan, seperti di Amerika Serikat, Inggris, dan di Australia. Partisipasi berkembang sejalan dengan perubahan struktur politik ke sistem demokrasi. Di mana sistem demokrasi memberi ruang yang cukup luas bagi masyarakat untuk turut berpartisipasi aktif dalam penyelenggara negara sehingga civil society dapat diwujudkan.

Pemahaman terhadap konsep partisipasi dalam banyak hal sering diartikan secara sederhana sebagai peran serta dalam suatu lingkungan kegiatan. Konsep peran serta dalam pengambilan keputusan dapat dijelaskan bahwa, peran serta (partisipasi) menunjukkan suatu proses antara dua atau lebih pihak (individu atau kelompok) yang mempengaruhi satu terhadap yang lainnya dalam membuat rencana, kebijakan, dan keputusan. Keputusan itu adalah sesuatu yang akan berpengaruh di kemudian hari bagi pihak pembuat keputusan, kelompok sasaran dan sering kali bagi lingkungannya. Dalam hal peran serta publik dalam rangka pembuatan kebijakan, tuntutannya tidak hanya timbul dari individu, tetapi setiap organisasi senantiasa harus

\footnotetext{
${ }^{11}$ Lijan Poltak, Op.Cit., hlm. 37-38.

${ }^{12}$ Muhammad Agus Yusoff, Op.Cit., hlm. 56.
}

mensyaratkan bahwa setiap keputusan yang akan diambil harus memperhitungkan pengetahuan dan pendapat dari orang-orang yang akan berpartisipasi dan mengambil bagian di dalamnya. ${ }^{13}$

Perencanaan perumusan dan pembuatan kebijakan publik dengan pendekatan partisipatif (participatory planning) sangat strategis, karena menjadi esensi mendasar dalam merangkum dan mengartikulasi aspirasi publik sebagai motor penggerak utama (main driving force) dalam setiap proses penentuan kebijakan. Menurut Friedmann, pendekatan partisipatif merupakan suatu proses politik untuk memperoleh kesepakatan bersama (collective agreement) melalui aktivis negosiasi atau urun rembuk antar seluruh pelaku pembangunan (stakeholders). ${ }^{14}$

Pendekatan partisipatif selain sebagai sebuah proses politik, juga merupakan sebuah teknis. Untuk proses ini lebih ditekankan pada peran dan kapasitas fasilitator (policy actor) untuk mendefinisikan dan mendeteksi stakeholders secara tepat. Selain itu proses ini juga diorientasi untuk memformalisasikan masalah secara kolektif, merumuskan strategi dan rencana tindak kolektif, serta melakukan mediasi konflik kepentingan dalam pemanfaatan sumber daya masyarakat. Salah satu hal penting ke arah ini adalah penguatan institusi masyarakat sebagai wadah untuk melakukan proses mobilisasi pemahaman, pengetahuan, gagasan, dan argumen menuju terciptanya kesepakatan bersama sebagai awal dari tindak kolektif penyelesaian

\footnotetext{
${ }^{13} \mathrm{Ibid}$.

${ }^{14}$ Muhammad Agus Yusoff, Op.Cit., hlm. 6.
} 
masalah dan pemenuhan kebutuhan publik.

Berdasarkan penjelasan di atas, dapat dirumuskan beberapa kriteria yang perlu dipenuhi dalam mengaplikasikan pendekatan partisipatif dalam setiap perencanaan pembangunan. Kriteria-kriteria yang dimaksud adalah: ${ }^{15}$

1. Pelibatan seluruh stakeholders untuk setiap arena perumusan dan penetapan kebijakan;

2. Penguatan institusi-institusi masyarakat yang legitimate untuk menyuarakan seluruh aspirasi yang berkembang;

3. Penciptaan proses-proses politik yang negosiatif untuk menentukan prioritas atas collective agreement;

4. Mendorong pemberdayaan masyarakat melalui pembelajaran kolektif sebagai bagian dari proses demokrasi.

Jika pelibatan masyarakat dalam pemerintahan sebagaimana secara teoritis diatas dapat terlaksana maka akan dapat menciptakan suasana pemerintahan yang bersahabat, karena jauhnya pemerintah -dalam hal ini birokrasi pemerintah- dari masyarakat akan ikut menjauhkan hasil rumusan kebijakan yang berpihak kepada masyarakat. Disamping itu, penilaian masyarakat akan keberadaan birokrasi pemerintah akan menjadi tidak baik. Sebab birokrasi pemerintah dihadapan rakyat yang powerless seringkali disebut kerajaan pejabat yang jauh dari rakyatnya ${ }^{16}$.

Perencanaan perumusan dan pembuatan kebijakan publik dengan pendekatan partisipatif (participatory

\footnotetext{
${ }^{15}$ Ibid., 7.

${ }^{16}$ Lihat Miftah Thoha, Birokrasi dan Politik di Indonesia, (Jakarta: Rajagrafindo Persada, 2003), hlm. 2.
}

planning) sangat strategis, karena menjadi esensi mendasar dalam merangkum dan mengartikulasi aspirasi publik sebagai motor penggerak utama (main driving force) dalam setiap proses penentuan kebijakan. Menurut Friedmann, pendekatan partisipatif merupakan suatu proses politik untuk memperoleh kesepakatan bersama (collective agreement) melalui aktivis negosiasi atau urun rembuk antar seluruh pelaku pembangunan (stakeholders). ${ }^{17}$

Pendekatan partisipatif selain sebagai sebuah proses politik, juga merupakan sebuah teknis. Untuk proses ini lebih ditekankan pada peran dan kapasitas fasilitator (policy actor) untuk mendefinisikan dan mendeteksi stakeholders secara tepat. Selain itu proses ini juga diorientasi untuk memformalisasikan masalah secara kolektif, merumuskan strategi dan rencana tindak kolektif, serta melakukan mediasi konflik kepentingan dalam pemanfaatan sumber daya masyarakat. Salah satu hal penting ke arah ini adalah penguatan institusi masyarakat sebagai wadah untuk melakukan proses mobilisasi pemahaman, pengetahuan, gagasan, dan argumen menuju terciptanya kesepakatan bersama sebagai awal dari tindak kolektif penyelesaian masalah dan pemenuhan kebutuhan publik.

Secara umum pemerintah
berperan untuk menciptakan
lingkungan politik dan hukum yang
kondusif, sedangkan sektor privat
memiliki peran untuk menggerakkan
dunia usaha sehingga dapt
memberikan lapangan pekerjaan dan
pendapatan. Sementara masyarakat

${ }^{17}$ Muhammad Agus Yusoff, Op.Cit., hlm. 6. 
sipil berperan untuk memfasilitasi interaksi-interaksi sosial politik dan memobilisasi kelompok-kelompok masyarakat untuk berpartisipasi dalam aktivitas politik, ekonomi, sosial, dan budaya. Khusus untuk masyarakat sipil, peran yang dimilikinya dapat dijabarkan lebih lanjut dalam hal berikut ini: ${ }^{18}$

1. Menciptakan power balancing system atau sistem yang mampu memberikan keseimbangan kekuatan bagi kekuatan pemerintah dan sektor privat, terutama dalam proses pembentukan kebijakan publik;

2. Berupaya menghilangkan potensi ketidakstabilan politik dan ekonomi dengan membuat mekanisme yang efisien untuk mengalokasikan keuntungankeuntungan sosial bagi masyarakat luas;

3. Mengisi atau memperkecil kesenjangan yang terjadi akibat adanya kegagalan pasar.

Secara umum kualitas good governance dapat tercapai apabila pemerintah dan institusi publik lainnya secara keseluruhan mampu bersikap terbuka terhadap ide dan gagasan baru dan responsif terhadap kepentingan warga masyarakat. Responsifitas akan meningkat jika masyarakat memiliki informasi yang lengkap mengenai proses dan implementasi kebijakan pemerintahan dan pembangunan. Demikian pula memahami dengan baik dan cermat akan tanggung jawab kolektif mereka terhadap institusi publik. Faktor lain yang juga memiliki peran sangat penting dalam upaya pencapaian good governance adalah norma, etika, dan nilai yang dapat mendorong dan menguatkan

${ }^{18}$ Ibid. masyarakat dalam memberikan kontrol terhadap jalannya pemerintahan dan pembangunan guna menjamin hak-hak setiap orang. ${ }^{19}$

Salah satu kunci utama dari pengelolaan kebijakan yang berkualitas adalah tingginya intensitas partisipasi publik. Sebab kesahihan kebijakan publik apa pun dari pemerintahan terletak di sana. Dialog dengan publik adalah kebenaran suatu kebijakan dan menjadi sarana utama untuk kebijakan yang siap digunakan. Perbincangan mengenai partisipasi dalam pengelolaan sektor publik telah lama mendapat perhatian serius di berbagai negara. ${ }^{20}$ Di negara maju $^{21}$ partisipasipasi publik telah lama menjadi agenda yang mapan dalam sistem pemerintahan dan pembangunan untuk setiap proses pengambilan keputusan, seperti di Amerika Serikat, Inggris, dan di Australia. Partisipasi berkembang sejalan dengan perubahan struktur politik ke sistem demokrasi. Di mana sistem demokrasi memberi ruang yang cukup luas bagi masyarakat untuk turut berpartisipasi aktif dalam penyelenggara negara sehingga civil society dapat diwujudkan.

Pemahaman terhadap konsep partisipasi dalam banyak hal sering diartikan secara sederhana sebagai peran serta dalam suatu lingkungan kegiatan. Konsep peran serta dalam pengambilan keputusan dapat dijelaskan bahwa, peran serta (partisipasi) menunjukkan suatu proses antara dua atau lebih pihak (individu atau kelompok) yang mempengaruhi satu terhadap yang

\footnotetext{
${ }^{19}$ Ibid., hlm. 51-52.

${ }^{20}$ Ibid., hlm. 36-37.

${ }^{21}$ Muhammad Agus Yusoff, Op.Cit., hlm. 56.
} 
lainnya dalam membuat rencana, kebijakan, dan keputusan. Keputusan itu adalah sesuatu yang akan berpengaruh di kemudian hari bagi pihak pembuat keputusan, kelompok sasaran dan sering kali bagi lingkungannya. Dalam hal peran serta publik dalam rangka pembuatan kebijakan, tuntutannya tidak hanya timbul dari individu, tetapi setiap organisasi senantiasa harus mensyaratkan bahwa setiap keputusan yang akan diambil harus memperhitungkan pengetahuan dan pendapat dari orang-orang yang akan berpartisipasi dan mengambil bagian di dalamnya. ${ }^{22}$

Untuk itu, partisipasi kebijakan adalah suatu aktivitas, proses, dan sistem pengambilan keputusan yang mengikutsertakan semua elemen masyarakat yang berkepentingan terhadap sukses suatu rencana. Tujuan utama dari partisipasi adalah mempertemukan seluruh kepentingan yang sama dan yang berbeda dalam suatu proses perumusan dan penetapan kebijakan (keputusan) secara proporsional untuk semua pihak yang terlibat dan terpengaruh oleh kebijakan yang akan ditetapkan dalamnya. Pelibatan masyakat luas (publik) dalam proses penentuan kebijakan merupakan satu cara efektif untuk menampung dan mengakomodasi berbagai kepentingan yang beragam. Pengikutsertaan publik yang terwujud dalam perencanaan yang partisipasi dapat membawa keuntungan substansif, di mana keputusan publik yang diambil akan memberi rasa kepuasan dan dukungan publik yang cukup kuat terhadap suatu proses pembangunan. Keterlibatan masyarakat dalam

${ }^{22}$ Ibid. proses penentuan kebijakan publik yang dapat memberikan nilai strategis bagi masyarakat itu sendiri menjadi salah satu syarat penting dalam upaya pembangunan politik, ekonomi, sosial, dan budaya. ${ }^{23}$

Perencanaan perumusan dan pembuatan kebijakan publik dengan pendekatan partisipatif (participatory planning) sangat strategis, karena menjadi esensi mendasar dalam merangkum dan mengartikulasi aspirasi publik sebagai motor penggerak utama (main driving force) dalam setiap proses penentuan kebijakan. Menurut Friedmann, pendekatan partisipatif merupakan suatu proses politik untuk memperoleh kesepakatan bersama (collective agreement) melalui aktivis negosiasi atau urun rembuk antar seluruh pelaku pembangunan (stakeholders). ${ }^{24}$

Pendekatan partisipatif selain sebagai sebuah proses politik, juga merupakan sebuah teknis. Untuk proses ini lebih ditekankan pada peran dan kapasitas fasilitator (policy actor) untuk mendefinisikan dan mendeteksi stakeholders secara tepat. Selain itu proses ini juga diorientasi untuk memformalisasikan masalah secara kolektif, merumuskan strategi dan rencana tindak kolektif, serta melakukan mediasi konflik kepentingan dalam pemanfaatan sumber daya masyarakat. Salah satu hal penting ke arah ini adalah penguatan institusi masyarakat sebagai wadah untuk melakukan proses mobilisasi pemahaman, pengetahuan, gagasan, dan argumen menuju terciptanya kesepakatan bersama sebagai awal dari tindak kolektif penyelesaian

\footnotetext{
${ }^{23}$ Lijan Poltak, Op.Cit., hlm. 37-38.

${ }^{24}$ Muhammad Agus Yusoff, Op.Cit., hlm. 6.
} 
masalah dan pemenuhan kebutuhan publik.

\section{Simpulan}

Adanya mekanisme konsultasi publik dalam perumusan kebijakan daerah dan peraturan ditingkat daerah sangat penting untuk membangun partisipasi publik. Akuntabilitas dan transparansi penyelenggaraan pemerintahan yang mengacu pada ketentuan peraturan perundangan yang berlaku akan menjadi sebuah prasyarat bagi partisipasi publik yang lebih intensif yang akan semakin meningkatkan kesadaran publik akan peran dan tanggungjawabnya dalam ikut menentukan keberhasilan penyelenggaraan pemerintahan dan perwujudan tata pemerintahan yang baik. Sinergi tersebut didasarkan pada prinsip kesetaraan, partisipasi, transparansi, akuntabilitas, demokratis saling menghormati sehingga pembangunan sistem pemerintahan yang lebih baik di daerah dapat segera diwujudkan. Sesuai juga dengan kebutuhan masyarakat dalam mewujudkan tata pemerintahan daerah yang baik. Hal ini dikarenakan penyelenggaraan otonomi daerah yang nyata dan bertanggung jawab di daerah memerlukan peran serta aktif dan nyata dari segenap komponen penyelenggaraan pemerintahan dan pembangunan. Dengan begitu, demokratisasi sebagai tiang penyangga utama pelaksanaan pemerintahan daerah akan terwujud apabila terjalin sinergi yang saling mendukung antara unsur pemerintahan, publik dan masyarakat pelaku usaha. Untuk itu disaran mekanisme konsultasi publik hendaknya dapat dimaksimalkan oleh masyarakat untuk terlibat dalam

pembentukan tata pemerintahan yang baik (good governance).

\section{Daftar Pustaka}

Aan Eko Widiarto, Garis Politik dan Peruandang-undangan dalam Desentralisasi Pengelolaan Lingkungan Hidup menuju Model Pengelolaan Lingkungan Hidup yang Berdimensi Peran Serta Masyarakat di Daerah, Skripsi, Malang, 1999.

Leo Agustio, Dasar-dasar Kebijakan Publik, (Bandung: Alfabeta, 2008).

Lijan Poltak Sinambela, Reformasi Pelayanan Publik; teori, kebijakan, dan implementasi, (Jakarta: Bumi Aksara, 2007).

Mas Achmad Santosa dan Arimbi BP, Peranserta Masyarakat dalam Pengelolaan Lingkungan Hidup, WALHI-YLBHI, Jakarta, 1993.

Miftah Thoha, Birokrasi dan Politik di Indonesia, (Jakarta: Rajagrafindo Persada, 2003).

Muhammad Agus Yusoff dan Rusman Ghazali, Otonomi Daerah, Partisipasi, dan Good Governance. Jurnal Ilmu Sosial dan Ilmu Politik LABSOSPOL FISIP - UNAS. 2003.

Pengantar Resensi buku
Memfasilitasi $\quad$ Kebijakan
Publik; Refleksi Pengalaman
Penyusunan $\quad$ Rancangan
Peraturan Pemerintah tentang
Tahapan, Tata Cara
Penyusunan, Pengendalian,
dan Evaluasi Pelaksanaan
Rencana Pembangunan
Daerah (RPP- T2CP2EPRPD)
yang diterbitkan oleh FPPM,
BIGS, USAID-DRSP dan
Dirjen Bina Bangda Depdagri.
Sebagaimana dipublikasikan


dalam

http://jrki.wordpress.com/categ

ory/resensi-buku/. 